\title{
XI'AN DAXUEXI ALLEY MOSQUE: HISTORICAL AND ARCHITECTURAL STUDY
}

\author{
Hagras, $\mathrm{H}$. \\ Islamic Archaeology dept., Faculty of Archaeology, Fayoum Univ., Fayoum, Egypt \\ E-mail:hmh00@fayoum.edu.eg
}

\begin{abstract}
As a part of ongoing research on representative Muslim architecture, including Chinese Mosques, this paper seeks to shed light on the cultural development and artistic features of ancient architecture of Chinese Muslims. The objective of this paper is to explore the characteristics of design and architecture of Chinese mosques. This article first depicts mosque history and architectural characteristics (planning, direction, internal structure, material, art performance and construction subsidiary, etc.). The mosque under consideration has a long history since its earliest construction during the Tang dynasty. It consists of a group of buildings forming introverted courtyard enclosed by halls and external walls which are known as Siheyuan. Chinese mosques are characterized by architectural forms different from the Islamic world architecture. Chinese Islamic architecture blends Islamic culture and content with traditional local Chinese heritage. This particular mosque is considered a typical ancient mosque, not only in Xi'an but also in China in general.
\end{abstract}

Keywords: Xi'an, Mosque, Siheyuan, Prayer Hall, Gabled roofs, Inscriptions

\section{Introduction}

Xi'an (西安) is a Chinese city, located on the Wei River basin of northwest China [1]. It is a strategic city and is the capital of the Shanxi province (陕西). The ancient name of the city was Chang'an (长安) [2] which remained in use up to 1369. The city was given its current name during the Ming dynasty (1368-1644) [1], and was the second capital of a united China [3]. Xi'an was the first Chinese city to be introduced to Islam. Chinese historians believe that Islam was introduced to China in $651 \mathrm{AD}[4,5]$. During the summer of the second year of the reign of the emperor Gaozong (高宗) (649-683) of the Tang dynasty (618-907) [6], the first Arab embassy was founded in Chang'an [7]. In fact, the Chinese sources confirm this contact; in Volume 221 (Western Regions) (西域) in the New Book of Tang (新唐书), an account of this embassy is as follows: "during the second year of the Yong Hui era (永徽), the court received an officially Arab envoy, and the Arabs give greeting from the king of the Arabs to the emperor" $[8,9]$. Since the establishment of that embassy, contact between the Arabs and Chinese became more frequent [10]. During the Abbasid era (750-1258), there were diplomatic relations between Arabs and the Tang dynasty [11-13], the most important of which occurred in 757 when Emperor Suzong (肅宗) (756762) asked the Abbasid caliph al-Mansur (754-775) to help quell an internal Tatar 
revolt. The Caliph accordingly set a military campaign of 10.000 soldiers [11]. The Islamic forces were able to control the capital Chang'an. Many of those soldiers settled in China and never returned to their homelands. Naturally, they married Chinese espouses, transplanted, and started the formation of Muslim communities in western China [12]. During the $10^{\text {th }}$ century, China witnessed successive waves of Muslim immigration. Chinese sources refer to the advent of Muslim mercenaries during the Song Dynasty. In 1070, Emperor Shenzong of Song (神宗) (1067-1085) brought a group of 5,300 Muslim mercenaries from Bukhara under the command of Prince Sayid Sofeier (索菲尔) to help him in his war against the Liao dynasty (916-1125). As a result, the emperor rewarded and granted them the right to settle in China [14]. In 1080, another group of more than 10,000 Arab men and women are said to have arrived in China on horsebacks to join Sofeier. These people settled in all provinces [15]. Another important form of connections was, however, made possible by trade. The silk route started around Chang'an and ended at the eastern shores

\section{Daxuexi Alley Mosque}

The Daxuexi Alley mosque Dàxuéxíxiàng Qīngzhēnsì (大学习巷清真寺), is located in Xi'an city in an area inhabited mainly by Chinese Muslims, in the street of Xidàjiēdàxuéxíxiàngnèi (西大街大学习 巷内) [24], fig. (1-a), near the Xi'an Huajuexiang mosque (化觉巷清真寺) -the great mosque-sometimes it is referred to as the Western Xi'an mosque (西大寺). In 1956; it was recognized as a Chinese historical heritage [24]. The names of this mosque have varied since its construction. During the Tang and the Song Dynasties, it was known as Tangmingsi (唐明寺). It became known during the Yuan dynasty as Huihui Wanshansi (回 of the Mediterranean. Two routes were accessible in and out of China: the nort hern route and the southern route [11]. Muslims, Arabs and, Persians gradually brought Islam to China as they settled and married Hans, converting them to Islam, while assimilating into the Chinese culture [16]. Traders flocked to China bringing along their religion and culture [17]. In fact, there are no accurate statistics on the number of Muslims in China. Researchers debated their numbers. Some scientists estimate their numbers as 20 million [18-20], while others like Gladney believe that the numbers exceed sixty millions [21]. Chinese Muslims form one of the most recognized ethnic groups in China. Chinese Muslims belong to ten ethnic groups, the largest of which is the Hui (回族, with a total population of approximately 10 million [22]. According to the census of 2015, the population of Xi'an was 8.7 Million [23]. The majority of residents belong to the Han minority, who makes up $99.1 \%$ of the total population. There are around 81,500 people belonging to ethnic minorities living in the city, including population with an estimation of 50,000 Muslims, the majority of whom hail from the Hui group [23].

回万善寺). The mosque acquired its current name during the reign of Emperor Hong $\mathrm{Wu}$ (洪武) of the Ming dynasty. The mosque has a long history since its construction during the Tang Dynasty. It was one of six mosques identified on the map of Shaanxi Shaanxi Sheng Cheng Tu (陕 西省城圖, which was created and published in 1893 during the era of Emperor Guang Xu (光者) (1875-1908) [24], fig. (1-b). Although the map does not include the names of the mosques, by comparison to Google maps reveals that the Daxuexi Alley mosque is located to the west of the Huajuexiang mosque. 

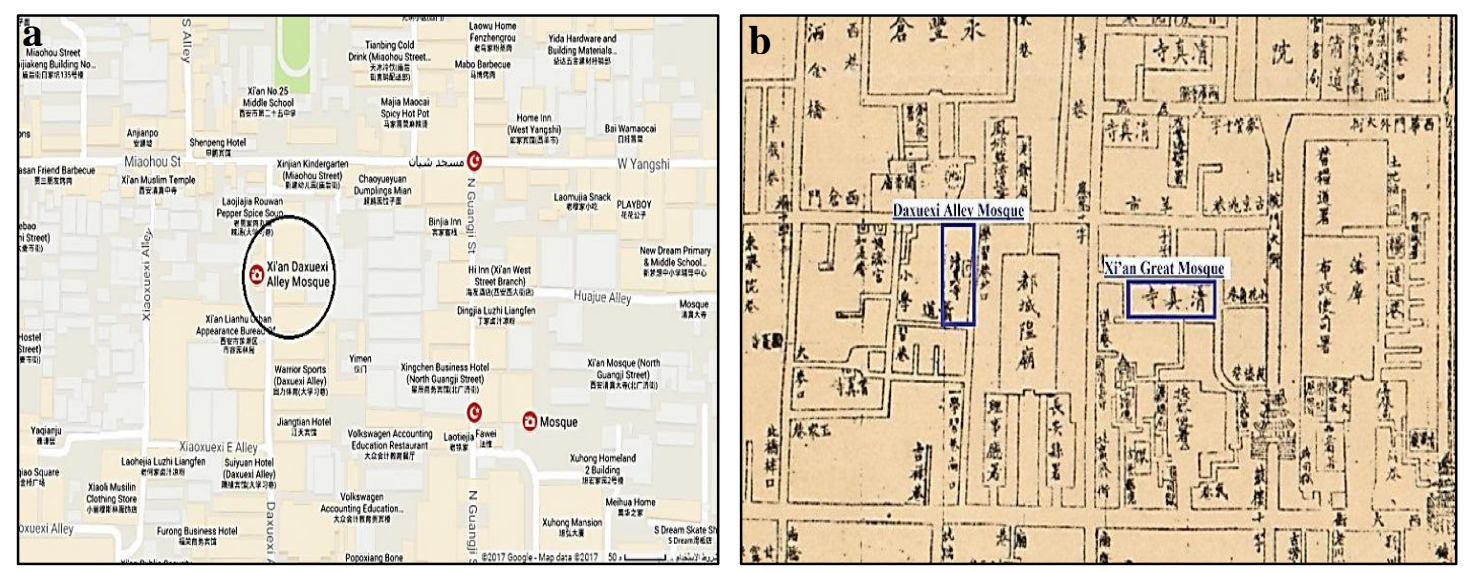

Figure (1) Shows $\underline{\mathbf{a}}$. location of Daxuexi mosque, $\underline{\mathbf{b}}$. Location of the mosque in the map of Shaanxi Sheng Cheng Tu (1893) [25]

\section{Approaching the Mosque}

The mosque is planned according to an East-West axis, and occupies a rectangular area (87 meters long and 37 meters wide with a well-arranged layout), with a total area of 3220 square meters, fig. (2). The mosque consists of a group of buildings forming an introverted courtyard enclosed by the halls and

external walls. The mosque combines several units: the great screen wall (照壁, the stone memorial archway (大〕), the Triple Room (三间庭, the Minaret (省心 阁), the Prayer Hall (礼拜大殿), the North and South Halls (南北厅), the Pavilions (碑亨), the Imam Office (阿言离), and the Ablution Hall (沐浴室) [5].

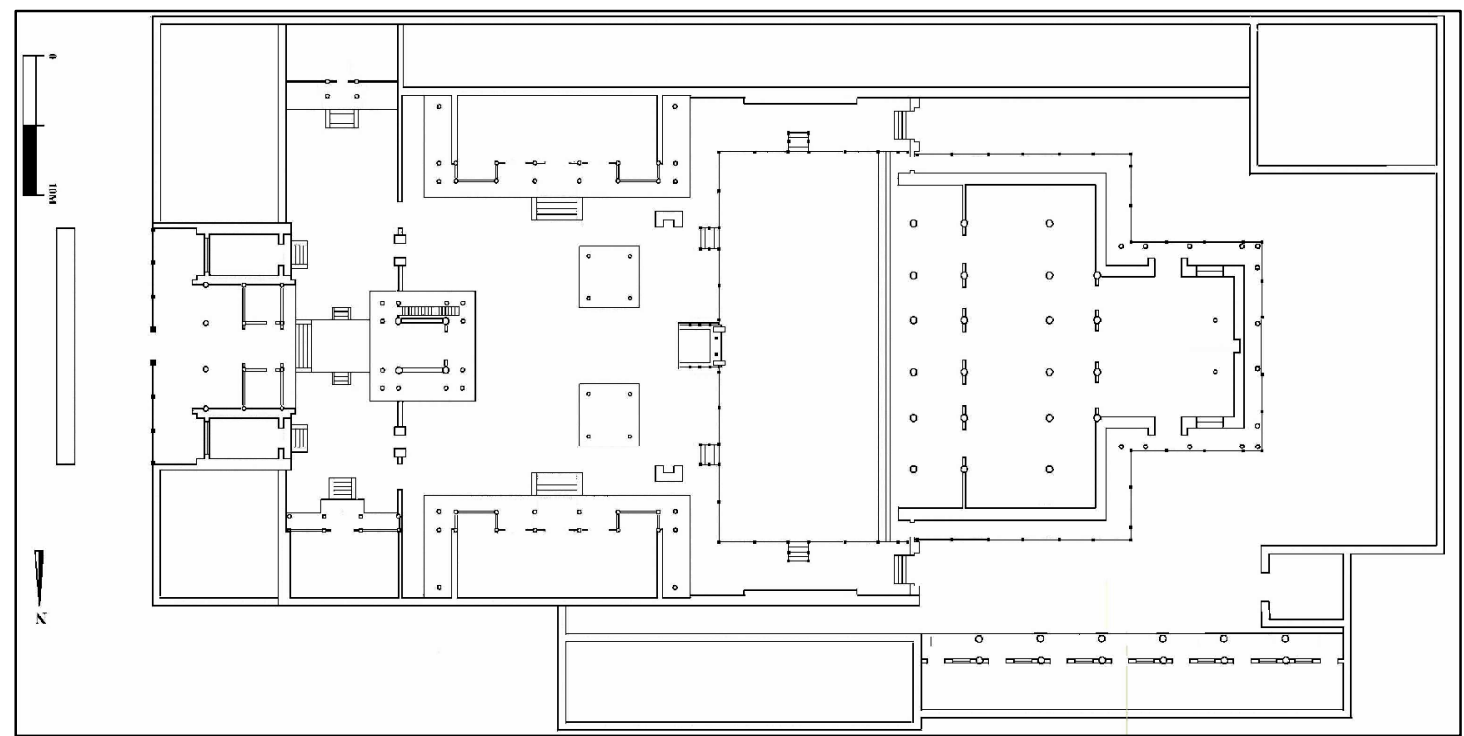

Figure (2) Shows the plan of Daxuexi Alley mosque

\section{External Façade and Entrance 4.1. The great screen wall}

The Screen wall, fig. (3) is located opposite to the main entrance of the mosque, it is very similar to its counterpart in Beijing, the Niujie mosque. It is a huge wall built of blue limestone, extending from north to south with a length of 17

meters, a thickness of 1.75 meters, and a height of 7 meters. The wall ends at the top with a Chinese gabled roof, decorated with Chinese decorative features such as ceramic tiles of roofs and animal sculptures. 
Figure (3) Shows the great screen wall

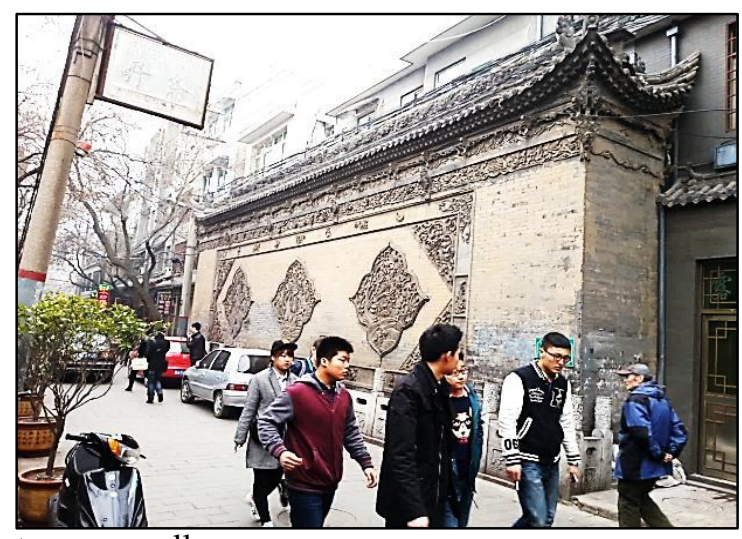

\subsection{Facade}

The eastern façade is the main one of the mosque, fig. (4), extending from north to south with a length of 17 meters, it is a stone arch consisting of eight square columns topped by stone thresholds. The middle columns are the largest and surround the entrance gate. The arch is decorated with floral motifs such as pomegranate, peony, and other flowers.

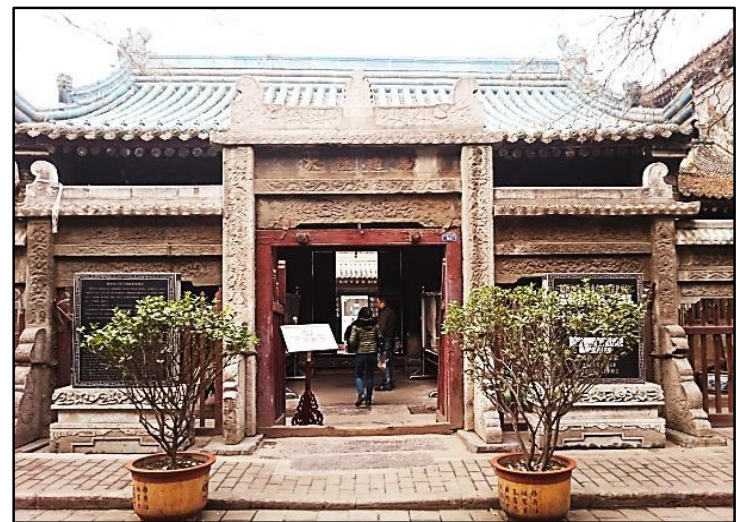

Figure (4) Shows the façade and the entrance

\subsection{The entrance area}

The entrance area occupies a rectangular area, which extends along the façade with a width of 3.6 meters. The western side is occupied by three architectural units: The middle represents the Triple Room Sānjiānting (三时庭) that leads into the mosque. On both sides, there are two units, each occupies a rectangular space (5 meters long and 3.5

\subsection{The forecourt}

The Triple room leads to the forecourt; this area is similar to its counterpart in Beijing's mosques such as Niujie mosque (北京牛街礼拜寺) and Changying mosque (常营清真古寺). It acts as a buffer area between the noisiness of the street world on the outside and silence of the mosque world on the inside, resembling a ziyada. It also acts as a separating zone between the entrance meters wide). The Triple Room is a rectangular area (the length from north to south is 8.75 meters, and from east to west is 7.6 meters), it is divided into three spaces, the largest of which is the middle space, and each covered with a gable roof which is known as Xieshanding (歇山顶).

gate and the courtyard [11]. This space occupies a rectangular shape with a length of 30.5 meters from north to south and width of 7.70 meters from east to west. Both the North and South sides are occupied by a hall, while the western wall is dominated by a minaret and a pair of entrances leading to the courtyard of the mosque. 


\subsection{The minaret}

The minaret of the mosque is known as Shengxinge (省心洛), fig. (5-a). It dates back to the Song dynasty (960-1279) [5]. However, its current building was constructed during the Ming dynasty by General Zhang He (郑和). The minaret is a wooden square structure built on a square platform with a length of 8 meters and its height is $60 \mathrm{~cm}$. The minaret has two levels of eaves that give an illusion of a two-story structure. The ground level story is a square area with a side length of 3 meters. Each corner has a cylindrical wooden column. This level has only two walls: the northern and southern walls. The eastern and western sides are holes with widths of $3 \mathrm{~m}$ and heights of $3 \mathrm{~m}$, preceded on the eastern side by a pair of stone drums which are known as Bàogǔshi [12]; the western side proceeds by five degrees. This area in the southern part contains a wooden staircase leading to the upper level of the minaret. The second level is a square area with a length of 3 meters and a height of 4 meters; it has an octagonal wooden column with a pair of double eaves raised on sets of dougong brackets. The building ends with a Chinese gabled roof which is known as shiziding (十字资顶 [26]. The minaret is flanked by two entrances similar to those in the Xi'an great mosque, fig. (5-b). This type of entrances is a traditional Chinese st- yle known as mánzimén (蛮子门) [27-29]. The two entrances are identical; each is a rectangular block built of brick, occupying a rectangular area that stands out from the sides of the wall by $30 \mathrm{~cm}$, the entry hole is $1 \mathrm{~m}$ wide and $2 \mathrm{~m}$ high, preceded by a pair of stone drums. The roof follows the traditional Chinese roofs xuanshanding (悬山顶) [30]; it is treated with Chinese decorative features. To the North and South sides of the minaret defined by a wall which pierced with a Three-quarter of a circle, this type is known as the moon gate yueliangmen (月亮门), the entry hole is a circle of 1.75 meters, decorated with an ornamental ribbon with motifs and ornaments. The entrances to both sides are dominated by Arabic inscriptions, example of which read: The Prophet said:

* "Scholars are heirs of the prophets"

* "The happy dwelling"

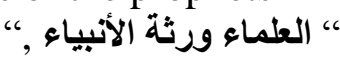

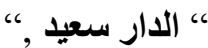

"The blessed palace"

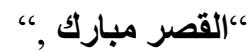

* "Seeking knowledge is obligatory for every Muslim“"

$$
\text { “طلب العلم فريضة على كل مسلم ومسلمة “، }
$$

* "The scholar is one hundred degrees more virtuous than the devout"

$$
\text { “بين العالم والعابد مائة درجة، }
$$

These examples are shown in fig. (5-c).
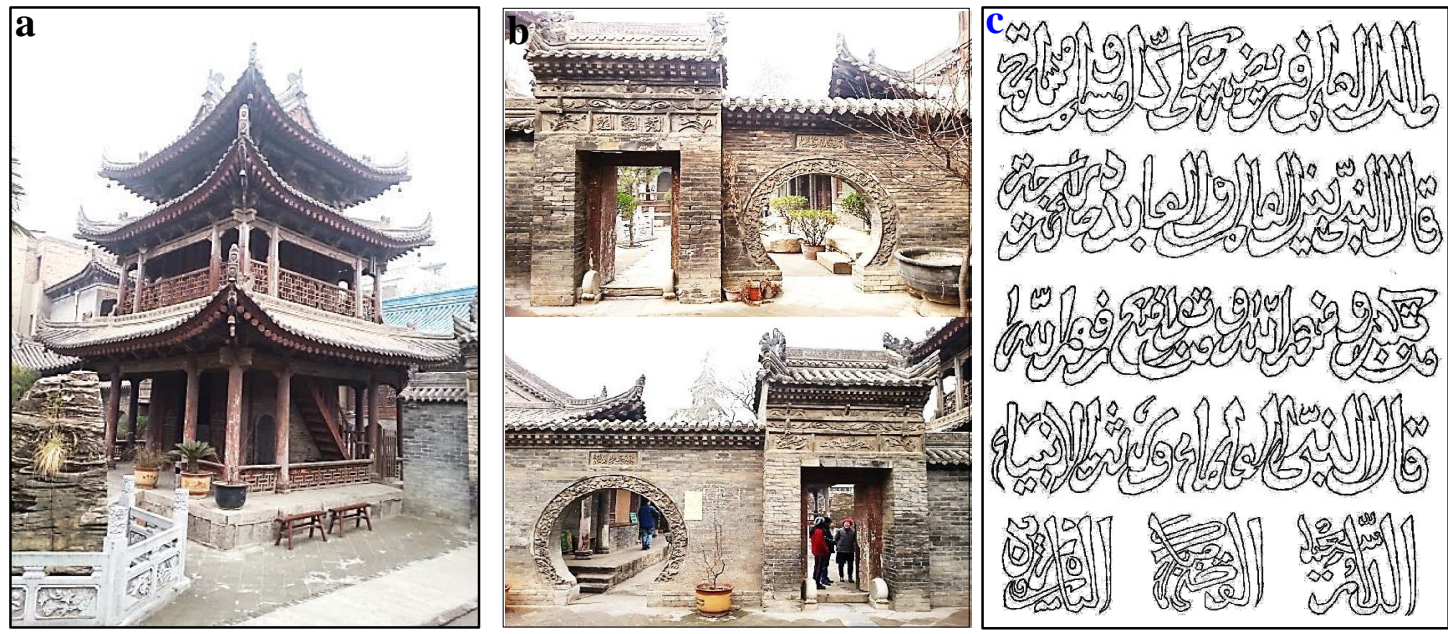

Figure (5) Shows $\underline{\mathbf{a}}$. the minaret of the mosque, $\underline{\mathbf{b}}$. the entrances of courtyard wall, $\underline{\mathbf{c}}$. the inscriptions of the entrances of courtyard wall 


\subsection{The courtyard}

The courtyard is a rectangular area with a length of 24.5 meters from east to west, and a width of 21.5 meters from north to south. The courtyard is bounded

\subsection{The pavilions}

The courtyard contains two pavilions; each of the pavilions follows the minaret in its form, details, and roof but lack the upper storey; they do not have a walled lower part. The two pavilions are symmetrical in both the general shape and the horizontal projection: each occupies a square area with a side length of 4.5 meters; each is based on a platform, topped by four cylindrical wooden columns, bearing traditional Chinese known as shiziding (十字背顶, it is a conical or hierarchical roof tapered whenever it

\subsection{The moon gates}

The North and South of the prayer hall are defined by the balustrade of the edge of the prayer hall on one side and the Southern and Northern walls of mirrors on the other. Each is an open passage with a length of 17.65 meters from north to south and a width of 3,65 meters from east to west. Two passages link the prayer hall courtyard with a smaller forecourt to the west. However, a transverse wall that links the sides of

\subsection{The prayer hall plinth}

This architectural element is an architectural tradition in ancient Chinese architecture, following the Chinese traditions. The prayer hall is given more attention being raised on a plinth. The plinth is a rectangular block with a length from east to west $(3,20$ meters) and from north to south (2, 90 meters). The entrance opening is 2 meters wide and is flanked by two square stone columns (pailou) carrying a stone lintel. The plinth is provided with a white stone parapet that circles the whole building which dates back to the Ming dynasty [5], pierced only where stairs allow access to the plinth's level. Stair flights are vis- by four gateways: two to the west and the others to the east and by two buildings to the north and south.

rises up. Each pavilion houses a stele with inscriptions. The southern pavilion is decorated with a stone stele dates to 1523, the second year of Ming Emperor Jia Jing (1521-1567); so this stele is known as stele of Jia jing, also known as stele of Zheng He (关俰碑) (d 1433 or 1435). This inscription is a testament to the extensive work and renovations of the mosque carried out by Zheng He. The northern stele is in Arabic bearing supplications and jurisprudence and dates to 1339.

the prayer hall with courtyard walls of the mosque obstructs the passage. The wall is pierced with a full circle with a diameter of 2 meters that is closed by a rectangular two-leaf wooden door. The purpose of these transverse walls is that it is the last area between the prayer hall and the large space of the mosque. The moon gates lead into a corridor that in turn leads to side gates of the prayer hall.

ually indicated by stone pai-lous, fig. (6). It is evident that the plinth's elements have received careful attention in terms of details and decorations. The parapet carved by Branches, flowers and pomegranate fruit. The stone pailou, too, show special attention to carved details and carry inscriptions in Arabic; example of which read:

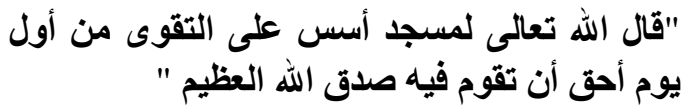

(God Almighty said: "It is more fitting that you should pray in a mosque founded on piety from the very beginning. Allah almighty has spoken the truth." Quran 9:108). 
Figure (6) Shows the entrance of plinth

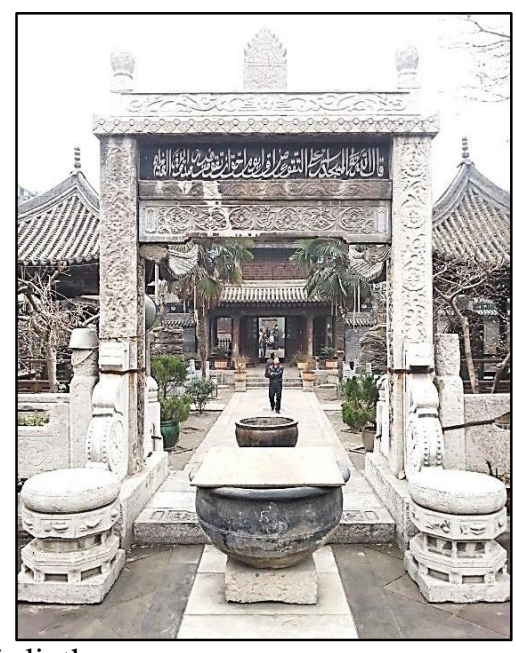

\subsection{The prayer hall}

The prayer hall is a wooden structure, it occupies an area shaped like 凸 it consists of three halls linked. The external walls are built of brick, which unifies the three halls composing the prayer area. The first two halls are covered with one gabled roof, while the western hall (Mihrab hall) has a separate roof, fig. (7-a). The first space of the prayer hall is known as Diànqián Juănpéng (殿前卷棚) [31] and acts as a vestibule that precedes the main or important space [11]. The first hall creates a rectangular area that measures 22X5 meters, its façade is totally walled with carved wooden partitions, which are pierced with five sets double-leafed doors. All the doors are carved with traditional Chinese scenes that are datable to the Ming dynasty. The prayer hall has a typical Chinese hipped roof with its usual accompanying dragons known as Xiānrénzóushòu (仙认走兽). This type of roof is Hip-and-gable Roof which is known as Xieshanding (歇山顶). The roof rests on the dougong (斗拱) system of brackets which in turn rests on the horizontal members carried by columns, fig. (7-b). The second hall is the main hall, masjid, known as Libàidiàn (礼舴殿), and occupies a rectangular area (22X10 meters). The hall contains one row of six freestanding wooden columns creating an interior of two unequal bays in depth, and seven equal isles in width. The western wall is pierced by three doors leading to the third hall (Mihrab hall). The third hall (Mihrab hall) is known as Hòuyáodiàn (后窑殿), fig. (7-c); it occupies a square plan $(10 \times 10$ meters $)$. Each of the Northern wall and the Southern wall has an entrance (width: 1.5 meters, height: 3 meters), each entrance stands out of the wall in the outward direction by half a meter, the decorations of these entrances have received special attention. A carved naturalistic panel decorates the façade. Like the Xi'an Huahuexiang mosque, the Mihrab hall has two central columns that precede the western wall (qibla wall) and have no apparent structural purpose. More likely, the columns serve the purpose of accentuating the qibla axis [11]. The Mihrab hall is the most outstanding and earliest square of the prayer hall. According to inscriptions of the stele of Jiaj ing, the Mihrab's architecture dates back to the reign of Emperor Jiaj ing of Ming, 1523. The walls of the hall are decorated with carved wooden panels. Although a small niche in the western wall indicates the actual Mihrab, the whole wall could be considered the Mihrab. The niche has a rectangular recess with pointed arch; the edge of the ache is decorated with parts of arches. The niche is mediated by the qibla wall. It is $80 \mathrm{~cm}$ wide, $50 \mathrm{~cm}$ deep and 2 meters high. Its back is decorated with vegetal designs. The niche is framed by 
three panels of Quranic inscriptions designed by two types of Arabic calligraphy: nakshi and kufi geometric, with a background of foliated winding stems. The external and internal panels read from right to left; it contains Quran 48:1-7, surat al-Fath, while the middle panel contains (Āyat al-Kursī) Al-Baqara
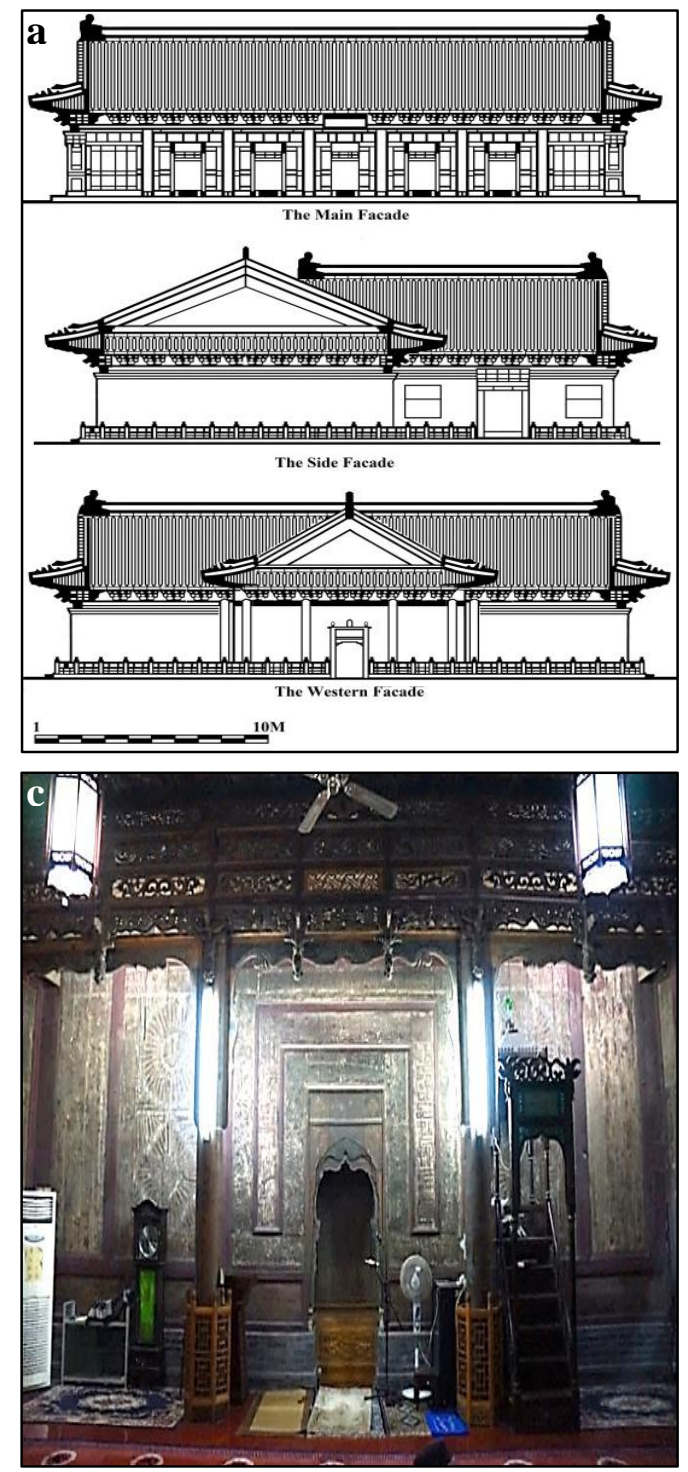

255, fig. (7-d). The roof is formed by painting square wooden panels fastened together, achieving the overall effect of a coffered roof. The panels are decorated with Chinese motifs as well as Arabic inscriptions that contain Allah's 99 names.
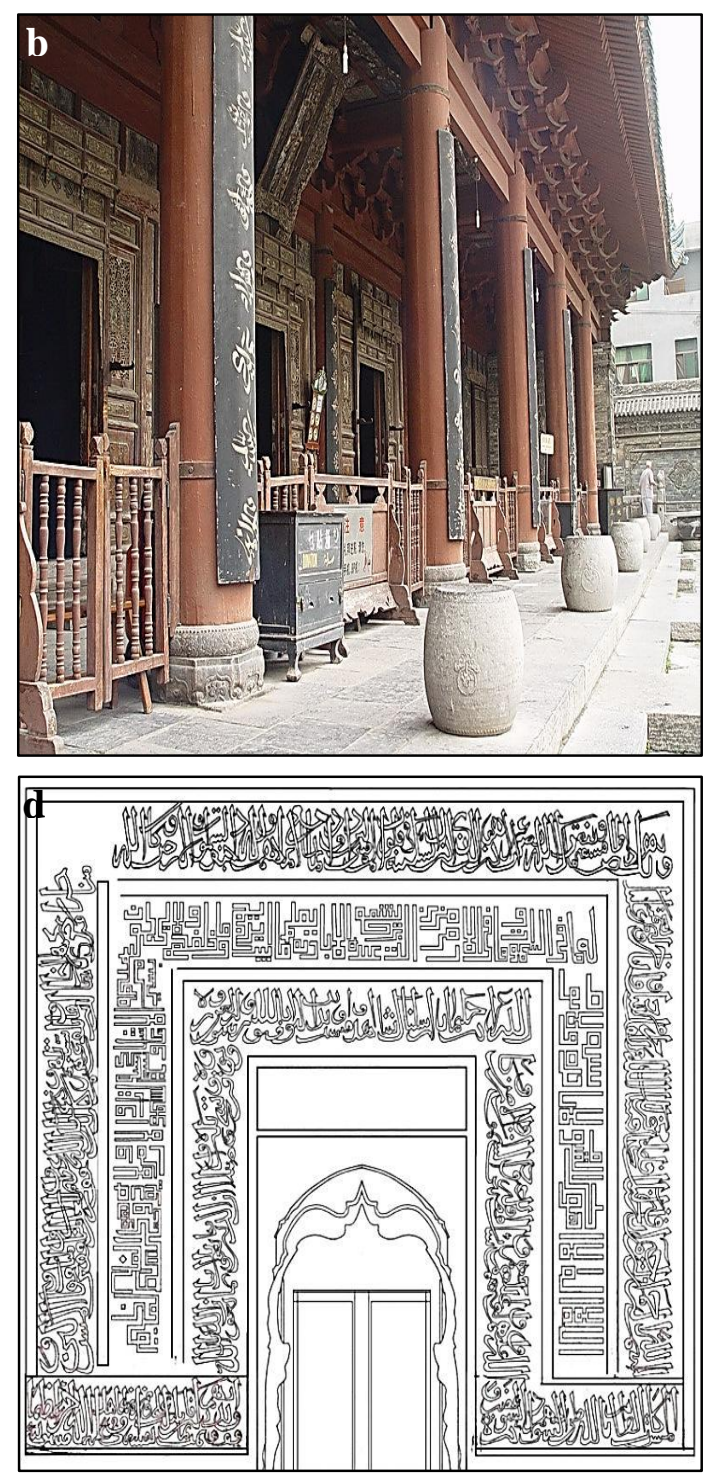

Figure (7) Shows $\underline{\mathbf{a}}$. the layout of prayer hall, $\underline{\mathbf{b}}$. the vestibule of the prayer hall, $\underline{\mathbf{c}}$. interior of the mihrab hall, $\underline{\mathbf{d}}$. the inscriptions of the qibla wall

\section{History of the Mosque}

It is widely believed by Chinese scholars that the mosque was initially built in 705 [5]; in fact, this estimation is supported by the inscription-which is still standing in the mosque - of the emperor Tian Qi (天启) (1620-1627) of the Ming Dynasty. It is explicitly stated that the mosque was built during the reign of the emperor Zhongzong (中宗).
According to the inscriptions, the mosque was enlarged and renovated during the Yuan dynasty (1279-1368) within the fourth year of the reign of the Emperor Kublai Khan Jong Tong (世祖 中统) (12601294) by Sayyid Ajal Shams al-Din Omar (赛典赤) (dead in 1279). The major reconstruction of the mosque was during the reign of the Yongle emperor (永乐) 
of the Ming dynasty by Tie Xuan (铁铉) and Zheng $\mathrm{He}$ (郑和) [24]. However, The mosque's architectural elements are similar to Xi'an Huajuexiang's mosque: the prayer hall, the qibla wall, the pavilions, marble bal-ustrade, the group's structural details, decorative themes, and visual aspects would be

\section{Discussion and Analytical Study}

The Daxuexi Alley mosque is one of the best Chinese mosques built according to traditional Chinese wooden architecture. The complex of the mosque also includes most of the architectural elements of this layout, such as the screen wall, entrance gate, pavilions, and tradi-

\subsection{Timber architecture}

During the Tang Dynasty, Chinese mosques initially reflected the characteristics of Islamic architecture, especially in Iran and Central Asia, such as the Qingjing mosque in Quanzhou, and the minaret of Huaisheng mosque in Guangzhou. But the culture of construction changed during the Song and Yuan Dynasties when the architectural style of Chinese mosques reflected the traditional Chinese style of architecture. The same approach continued during the Ming and Qing dynasties, reflecting the culture of Muslims who gradually merged into the local culture. Chinese

\subsection{Structure of units}

The architecture of the units has three levels: the platform, the building, and the ceiling [32]. The façade of the building is often wooden or brick walls interspersed with windows and entrances. The wooden ceiling consists of many pieces of wood, allowing construction to resist bending and twisting during earthquakes as well as high pressure caused by the heavy weight of the ceiling. The gabled roofs are often the main feature of Chinese wooden architecture, which are always covered with glazed tiles [12]. The use of wood as a construction material has emerged in some architectural elements of mosques, such as ceilings, triangular wooden cables Quètì (雀替), beams Liáng (梁), frieze yán (檐, dated to the reign of Jia Jing . During the Qing Dynasty, the mosque underwent two repairs; the first was in 1714 during the period of Kangxi (康熙) (1661-1722), while the second was in 1890 during the reign of Guangxu (光緒) (1875-1908). In 1956 it was listed as a Shanxi cultural heritage [24].

tional entrances, as well as the gates of the moon and the prayer area on the western side. Thus, the mosque is a typical ancient mosque not only regarding the city of Xi'an but also considering Chinese Islamic architecture in general.

Muslims have been considered Chinese citizens and have become contributors to the Chinese culture, which naturally was reflected in their architecture [12]. The local architectural heritage (traditional Chinese architecture) played a major role in the formation of the architecture of Chinese mosques. In fact, the architecture of the mosque in its general appearance -both its architectural elements and plans- adopted traditional Chinese architectural styles. The ancient Chinese architecture mainly consists of timber frames, wooden columns, beams, lintels, and dougong brackets [12].

doors, windows frames, Columns, and pins Ménzān (门笠) [12]. In the same context, we find that most of the ancient Chinese mosques built according to the style of Chinese temples, which depend on the planning of courtyards with enclosures and the use of traditional Chinese entrances [13]. Although the architecture of Chinese mosques follows the forms of local Chinese architecture, its different purpose and function from the Chinese temples have significantly distinguished it. Chinese Muslims introduced architectural and decorative units and elements that were not included in the Chinese temple architecture such as minarets, lecture halls, ablution spaces, etc [12]. 


\subsection{Planning concepts}

Like many local Chinese mosques, the planning concepts of the Daxuexi mosque follow essentially the norms of Chinese planning, layout, design, and traditional wooden structure. The mosque consists of two courtyards and an axial building line. The horizontal space of the building is constructed around foursided enclosures, siheyuan (四合院. Siheyuan is one of the most profound principles of ancient Chinese architecture [7]. The Wall is the most important Chinese planning feature, which makes each building nenclosed area isolated from its surroundings [33]. Although the courtyard, Sahn (صحن), is a common feature in most mosques of the Islamic world, the courtyard of Chinese mosques tends to have a different layout. A courtyard of a mosque in the Islamic world is an open extension of the prayer riwaq or iwan. The courtyards were usually surrounded by a riwaq that is, in fact, an integral part of the prayer area. On the contrary, the courtyard of a Chinese mosque is a space that connects the sur-rounding buildings. In other words, a courtyard of a mosque in the Islamic world could be described as one building encompassing an open courtyard, while the Chinese arrangement is of four or more buildings linked together by one courtyard [11]. Although the Southern-Northern orientation is a dominant feature of traditional Chinese architecture, the layout of mosques in China defies traditional Chinese planning. However; Chinese mosques have been affected by another factor that is more important and inevitable: the orientation of Mecca [11], all Chinese mosques had to face west [13], which is imposed by Islamic faith; so the direction of Daxuexi Alley mosque is East-west. Like other traditional Chinese temples and mosques, the Daxuexi Alley mosque has three main axes: a central axis that bisects the site and two parallel axes of the mosque entrance. However, the layout of this mosque is similar to many Chinese mosques: the Xi'an great mosque (西安化觉巷清真寺), fig. (8a), the Beijing Niujie mos-que (北京牛街 清真寺), fig. (8-b), the Guangzhou Huaisheng mosque (广州不圣寺), fig. (8-c, the Tongxin great mosque (同心清真大寺), fig. (8-d), and the Hangzhou Fenghuang mosque (杭州凤闰清真寺), fig. (8-e) Courtyards are among the most important features of traditional Chinese architectural planning [34]. The main buildings follow each other along the middle axis [13], proceeded by vast courtyards closed on the east and west by buildings of secondary importance [11].
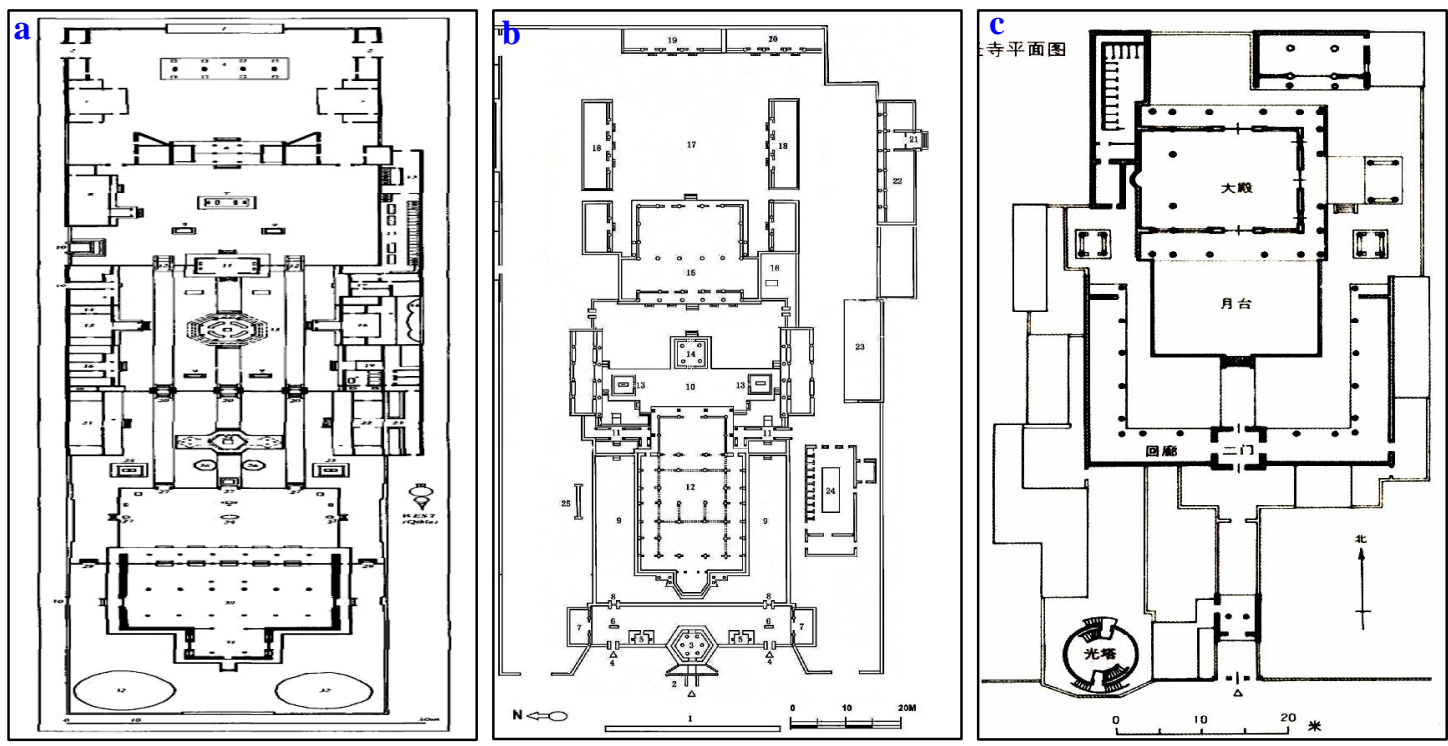

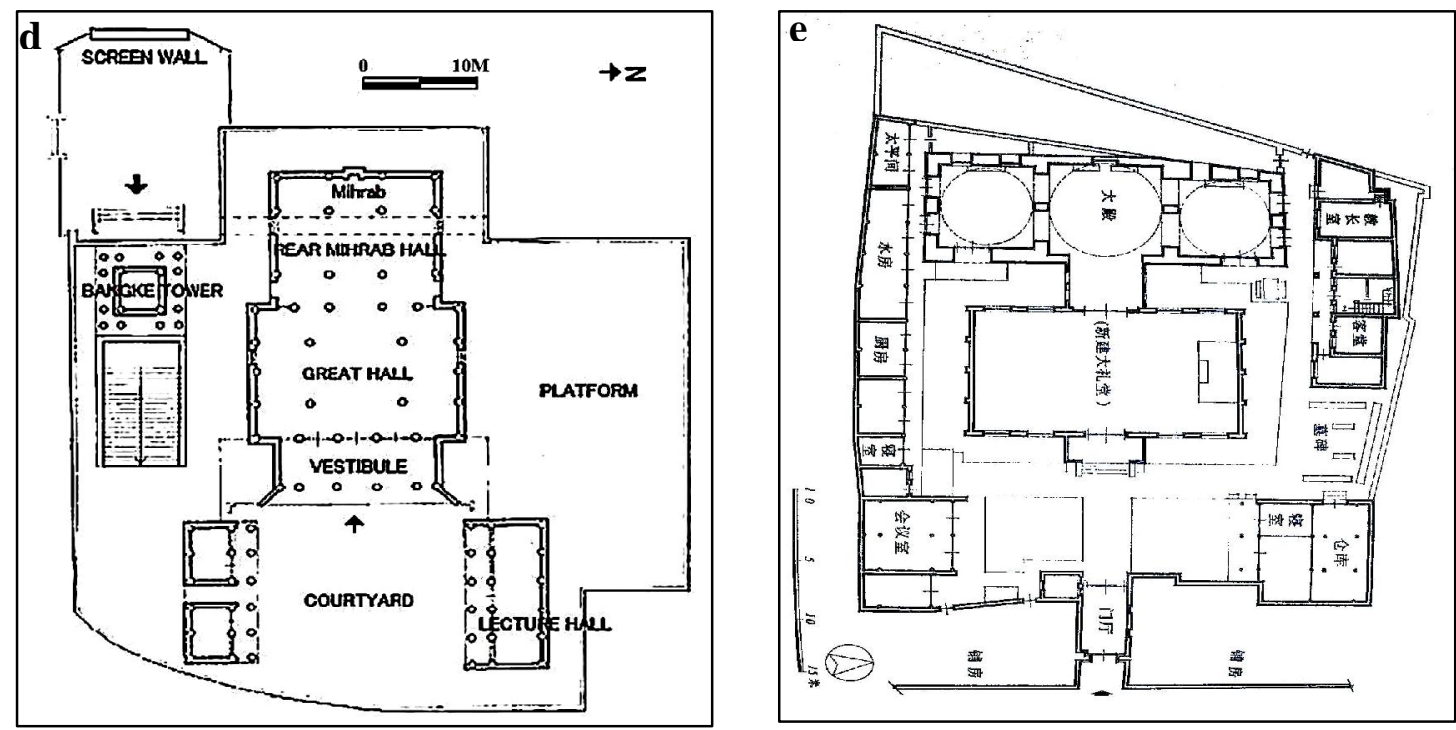

Figure (8) Shows plans of a. Xi'an great mosque [34] , $\underline{\mathbf{b}}$. Beijing Niujie mosque [12], $\underline{\mathbf{c} .}$ Guangzhou Huaisheng mosque [34], $\underline{\mathbf{d}}$. Tongxin great mosque [34], e. Hangzhou Fenghuang mosque [7]

\subsection{Minaret layout}

The Minaret is located in the main courtyard, not on the main façade. In contrast to the minarets of mosques of the Islamic world, the minarets of most Chinese mosques occupy the interior area of a mosque complex [12]. It seems that Chinese Muslims have built minarets inside the interior space of mosques in a way similar to the Pagodas that reside inside temples, which was imposed by the traditional planning of courtyards [12]. Also, although the minaret is an important architectural and functional element in Islamic architecture, high minarets were absent from Chinese mosques.

\subsection{Prayer Hall plan}

A prayer hall is the most important building in a mosque complex [35-37]. Architecturally, a prayer hall could be divided into three parts: the platform, the building, and the roof [11]. The main function of a platform Táiji (台基) [38] is to protect wooden architectural elements such as columns from erosion due to moisture [11], so it is always higher than the level of the courtyard floor [7]. The building is divided by the wooden columns of the structural system into horizontal and longitudinal bays [11]. A Prayer hall, like all prayer halls in Chinese mosques,

\subsection{Ceiling types}

Flat roofs are uncommon in traditional Chinese architecture while gabled

The height of minarets does not match the heights of pagodas and was not built with stones or bricks except its bases However, there is one exception: the minaret of the Guan-gzhou Huaisheng mosque (怀圣寺) which was built of stones and has a height of 36 meters [7]. The minaret of the mosque has a square plan, and thus differs from the layout of the minaret of the Xi'an Huajuexiang mosque which occupies an octagonal layout), fig. (8a). In terms of layout design, the Minaret is quite similar to its counterpart in the Tongxin Mosque), fig. (8-d).

features an open corridor surrounded from all sides except the eastern side which is occupied by a courtyard [7]. The plan of prayer hall is known as tūzìxíng (凸字形) [12,13]. This is the most widespread plan in Chinese mosques. The layout is usually a large area preceded by a smaller one in the west side (qibla). Many prayer halls in Chinese mosques follow this shape, such as the Xi'an Great mosque (西安化 觉巷寺), fig. (8-a) [11].

roofs are quite widespread [13]. Like many local Chinese mosques, Islamic roof forms 
were absent from the mosque and were replaced by traditional Chinese roofs. The gabled-roofs are the main means of covering the mosque. This type is one of the most important features of ancient Chinese architecture. These ceilings are mainly based on wooden columns; the side columns are lower than the central columns. The prayer hall is characterized by a type of gabled roofs: the hip and gable roof, fig. (7-a) [39,40] known as Xieshānding (歇山顶) [41], it covers a rectangular plan and has four faces that slopes down on all and merges a gable on two opposing faces, so that its front and rear sides are larger than others [42,43], and are integrated into the small sides of the top with two small sides [44]. This style is the best example of traditional Chinese gable roofs since its architecture enables it to withstand extreme weights due to its sharp angles and shallow slopes [45]. Beside hip and gable roof; there are many types: the hanging gabled roof is known as xuánshāndǐng (悬山顶 [33], it is also covering a rectangular plan, and has two long faces that slope down, while the two opposing faces are vertical [46]. This type is often used as a cover technique for the vestibule of the prayer hall; but in this particular mosque, the first hall (vestibule) and the second hall (great

\subsection{Architectural elements}

Wood and brick were the main construction materials of ancient Chinese architecture in which the construction of walls, beams, and piers was indispensable. As mentioned before, Muslim architects in China adopted such materials as an imitation of traditional Chinese architecture which adopted wooden arch-

\subsubsection{Screen wall}

A screen wall also called a spirit wall [26] or wall of mirrors [11], (Chinese: 影壁 pinyin: Y̌̌ngbì, or: 照壁 pinyin: Zhàobi) [27]. Yîngbì (影壁 is used to refer to walls on the outside, whereas zhaobi (照壁) is used to refer to walls positioned on the outside [27]. This arch- hall) are covered together with one roof which is a hip and gable roof. The hanging gabled roof is the main roof of many units in the mosque: the lecture halls, the vestibule of the prayer hall, and the entrance hall. The cross-gabled roof, known as Shizijíding (十字猆顶 [29], follows the construction style of traditional Chinese roofs [47]. It is used to cover square areas such as pavilions, towers, and minarets. The pavilions in the mosque are illustrations of this type. The custom of Chinese architecture is to cover the building with one roof [11]. However, in this particular mosque, the prayer hall is covered with two roofs, which are merged together using an architectural technique known as Gōuliánda (勾连塔) [48]. Consequently Chinese Islamic architecture stands out as distinct from other religious buildings in China [34]. This technique allowed architects to expand and increase the area of a prayer hall without the demolition of any preexisting structures [49]. So, relying on this method offered a cheaper alternative and solution for Chinese Muslim architects to expand prayers spaces without having to build new structures [12]. The roof is hipped and tiled with sky-blue glazed tiles.

itecture as the architecture of choice. However, several architectural elements have emerged in Chinese mosques that have not been found in the mosques of the Islamic world such as the screen wall, dougong brackets, stone drums, platforms, etc.

itectural element has many functions in traditional Chinese architecture and is mainly used to shield an external and an interior gate. According to Chinese legends, this wall prevents the entry of evil spirits, ghosts, and demons, and is also meant to avoiding bad luck [28]. 


\subsubsection{Entrances}

Entrances are important architectural elements in traditional Chinese architecture, as well as Islamic architecture. The Arab-styled entrances were absent from the mosques of the inner provinces of China except for two mosques: the Hangzhou Fenghuangsi Mosque (杭州风 凰寺) and the Quanzhou Qingjingsi Mosque (泉州清净寺); the entrance to the last mosque is the only example of stone entrances [10, $12,34]$. It is worth mentioning that since the Yuan dynasty (1271-1368) the styles of entrances that follow traditional Chinese architecture have been adopted [10, 12,34]. When constructing entrances, several important points were taken into account. All entrances are located at the main façade, so the entrances are opened by the eastern wall of the mosque; the entrance was paved with a pair of stone

\subsubsection{Stone drums}

Stone drums are known as Bàogǔshi (抱鼓石) and are considered of the utmost important stone elements of ancient Chinese architecture. They serve many functions: in addition to their decorative function, they have a structural purpose, which is being used as a base to embrace

\subsubsection{Platform}

A platform is known as taiji (台基) [38] and is an indispensable feature of traditional Chinese architecture. Its main function is to protect wooden architect-

\subsubsection{Dougong Brackets}

Brackets are among the most important elements of ancient Chinese wooden architecture [50], known as dǒugǒng (斗拱) [38,51]. A dougong consists of many intersecting and intertwined wooden pieces, in other words, it is a portion of the network of wooden props fundamental to the timber frame structure of traditional Chinese wooden architecture because the walls in these structures are not the main load-

\subsection{Decorations}

There were many ways and methods of decoration in mosques. In addition to the use of colors in the decoration, drums. This element was meant to add significance to the interior architecture of a building [12]. The mosque has many types of entrances; the entrance hall ménlóu (门楼 [39], is a vestibule representing the entrance block of the mosque, is located on the eastern side. Its facade overlooks the main street with an arcade of cylindrical wooden columns. The entrance wall is pierced with a door leading into the hall [12]. The moon gate yueliangmen 月亮门 is also a traditional Chinese architectural element, and its shape is a circular opening in a wall that acts as a pedestrian passageway. The memorial entrance mánzimén 蛮子门[30-32] is one of the most luxurious entrances in the ancient Chinese architecture, which is composed of a pair of pillars enclosing openings on both sides [12].

columns of doors. A stone drum consists of two parts: the upper is a circular drum decorated with floral motifs, and the bottom is a base known as the drum base, as well as the inner part of the door column [12].

ural elements such as columns and walls from the sever effects of corrosion processes due to moisture [11].

bearing structures. A dougong is among the most intricate architectural elements in wooden structures [52], because its structure renders it the least affected architectural element by earthquakes due to its flexibility and strength, which is capable of absorbing vibrations [53]. In addition to its structural function, it was used as a decorative element [54].

different ornaments were used in various shapes. 


\subsubsection{Colors}

Colors played an important role in the decoration of traditional Chinese wooden architectural structures. Chinese craftsmen were able to perform it with great skill, so colors are of the main features and characteristics of ancient Chinese architecture. The purpose of colors was of functional and practical necessities to protect the wooden elements from weather factors and avoid erosion [12]. The dec-

\subsubsection{Glazed tiles}

Decorative glazed tiles are known as liúlíwă (琉离瓦) [38]. They are among the most important architectural decorations of ancient China. Besides its deco6.8.3. Figurines

Although Chinese Muslims relied on figures, they did not use them in the prayer area, because Islam forbade their use. In other words, Muslim artists have harmonized religious rules along with religious traditions on the one hand and local art traditions on the other. The use

\subsection{Inscriptions}

The mosque contained a good number of inscriptions that varied in its material, whether wooden or stone. These inscriptions were dominated by three languages: Arabic, Persian and Chinese. The inscriptions of mosques were initially based on Arabic and Persian [12], such as the inscriptions of the Quanzhou Qingjingsi mosque (泉州清净寺) which was dominated by the Arabic [57], as well as the inscriptions of the tomb of Baha al-Din (扬州仿作曾哈丁墓) in Yangzhou [58]. The Chinese language began to emerge gra-dually since the late Yuan dynasty (1271-1368) [59] in line with the development of Chinese Muslim societies and evidence of their gradual integration into local Chinese culture. They were not seen as foreigners and strangers and began to be seen as Chinese citizens. It is noted that the Chinese orations of mosques with colors follow traditional Chinese cultural norms. The color red is prominent due to the cultural influences of the Han, who used it to express happiness [55]. As such, it was used in the prayer hall, as well as the blue, yellow and green colors which were used to decorate the glazed tiles, while the grey and black colors were the colors of preference for roof exteriors [12].

rative functions, it also helps to drain rainwater and protect roofs from corrosion effects [56].

of animal figures inside the prayer hall was neglected. Animal representations only adorned the roofs of buildings. According to Chinese culture and beliefs; the purpose of using this type of décoration is to protect buildings from different evil spirits [11].

language was not used inside the prayer area; it was a prefe-rence to use it outside. Perhaps this is due to the fact that it did not fit with the Quranic drawings, acoustics, and exegesis of the Quranic verses and supplications [12]. The contents of the mosque inscriptions are varied and can be categorized into three main types: foundation or restoration inscriptions, short message or couple, and Quranic and Hadith quotations. Foundation or restoration inscriptions in the mosque follow Chinese tradition in recording the foundation or restoration of the building on stone slabs. The stele of Jia Jing is the most important one in the mosque; it represents the architecture reforms and innovations of the mosque since the Yuan period until the Ming period.

\section{Conclusion}

The Xi'an Daxuexi Alley Mosque follows essentially the norms of Chinese planning and layout design and wooden structures. As for the architectural aspects, Chinese Islamic architecture added new styles not seen in the Islamic world, but contributed to the diversity of architectural 
styles offered by mosques in the Islamic world. Although many believe Chinese mosques complied and surrendered to the style of the Chinese traditional architecture, the Chinese Islamic architecture differes from other Chinese religious architecture. The North-South orientation is a dominant feature of traditional Chinese architecture, the layout of local Chinese mosques defies that orientation. Perhaps the main reason for this is compliance with Islamic law that requires direction of the building towards the Qibla (the orientation of Mecca), so the direction of most Chinese mosques is East-west. Also, Chinese mosques contain many multi-functional architectural units. The role of the mosque in China was not limited to prayers, but was a place for religious instruction and meetings. The various sources of funding for mosques in China have had a great impact on the continuity of its functions during different ages to meet the demands of the Islamic community and achieve its objectives. The construction of most local Chinese mosques depended mainly on donations from Muslim leaders; the Muslim community was a patron of Islamic art to serve their religious activities. Inscriptions of the Daxuexi Alley mosque reveal to us the names of many Muslims who contributed to the construction of the mosque such as Sayyid Ajal Shams al-Din Omar, Tie Xuan, and Zheng He. The mosque is a witness of political relations between Muslims and Chinese court and a proof of the religious tolerance policy of the Yuan and Ming emperors towards Muslims. The mosque was reconstructed during the era of Emperor Kublai Khan, and underwent extensive expansion during the Ming period as a reward for General Zheng $\mathrm{He}$ after his voyage in West Asia. The Arabic and Persian calligraphies served as a bridge between Muslims of China and the Muslim world. Inscriptions of mosques were initially based on the Arabic and Persian. During the Ming Dynasty, the Chinese language began to appear in use in mosques. This period witnessed great literary works in Chinese by Muslims, in various fields such as law, philosophy, religious jurisprudence, etc. The decoration of the mosque was mainly based on the motifs of traditional Chinese architecture, along with Arabic script inscriptions derived from the Qur'an and Islamic faith. Although Chinese decorations were preferred, the mosque did not contain statues and figurines in compliance with the Islamic religious laws.

\section{References}

[1] Silverman, N., (2012). The Oxford companion to archaeology, Vol. 1, $2^{\text {nd }}$ ed., Oxford Univ. Press, NY.

[2] Dillon, M., (2016). Encyclopedia of Chinese history, Taylor \& Francis, NY.

[3] Tellier, L., (2009). Urban world history: An economic and geographical perspective, Presses de l'Université du Quebec, Canada .

[4] Leaning, M. \& Pratt, D., (2012). Islam in China, from Silk Road to separatism, The Muslim World, Vol. 102, pp: 308-335.

[5] Chenyu, N. \& Tang, X., (2007). 中国回族文物 (Relics of Chinese Hui minority), Ningxia: Renmin Press, Ningxia.

[6] Xue,Z., (2000), 怛逻斯之战历史朔㟲唐与 大食百年政治关系述略651-751) (Historical origins of the talas campaign: A brief construction on political relations between the Tang and Arab from 651 to 751), 中国边疆史 地研究 Vol. 10 (4), pp: 85-100.

[7] Steinhardt, N., (2008). China's earliest mosques", J. of the Society of Architectural Historians, Vol. 67 (3), pp: 330-361.

[8] Xin Tangshu, (1975). 新唐書 (New book of Tang history), $\mathrm{Vol}_{\mathrm{s}}$. 38-350, Zhonghua Press, Beijing.

[9] Wangxiao, F., (1992). 史政大吐唐治 食蕃关系(History of relations between Tang and Arabs), Beijing Univ. Press, Beijing.

[10] Liuzhi, P., (2008). 中国(斯”教建筑 (Chinese Islamic architecture), Xinlian House Publishing, Beijing.

[11] Wahby, A., (2000), Islamic architecture in China, mosques of eastern China, MA, School of Humanities and Social Sciences, The American Univ. in Cairo, Cairo.

[12] Hagras, H., (2016). Almasajid al'athariat albaqiat fi madinat beijing mundh alqarn alrrabie alhijrii (aleashir almiladi) wahati nihayat alqarn alththalith eshr alhajrii (alttasie eshr almylady) "drasat 'athriat muemaria" (Beijing monumental mosq- 
ues since the fourth century until the Nineteen century "architectural archaeological study"), $\mathrm{PhD}$, Islamic Archaeology dept, Faculty of Archaeology, Fayoum Univ, Egypt.

[13] Hagras, H., (2017). An ancient mosque in Ningbo, China: historical and architectural study", J. of Islamic Architecture, Vol. 4 (3), pp: 102-113.

[14] Israeli, R., (2012). Islam in China, politics and religion in contemporary China, Vol. 5 (2), pp: 251-268.

[15] Israeli, R., (2002). Islam in China, religion, ethnicity, culture and politics, Lexington Books Press, Boston

[16] Lipman, J. (1997). Familiar strangers, A history of Muslims in northwest China,: University of Washington Press, USA

[17] Zhangzhong, F., (2001). 清代西北 回民事变一社会久化适应与民族人同的省 思 (The Muslim rebellions in the northwest during the Qing dynasty), Lianjing press, Taipei.

[18] Huzhen, H., (2006). 民族文化研究文集 (Anthology of cultural studies), Zhongyang Univ. for Nationalities Press, Beijing.

[19] Pew Research Center (2009). Mapping the global Muslim population: A report on the size and distribution of the world's Muslim population, The Pew Forum on Religion \& Public Life Press. Washington

[20] Boston, D. \& Zhang, A., (2010). The Muslim minority nationalities of China toward separatism or assimilation, Population Association of America, USA.

[21] Gladney, D., (2008). Islam and modernity in China, secularization or separatism, Chinese religiosities, Afflictions of modernity and state formation, University of California Press, Berkeley

[22] Qian, Z., (2009), China's ethnic groups and religions, China International Press. Beijing

[23] Yu, Z., (2014), Investigation of historical area in Xi'an, China, MA,: University of MassachusettsAmherst, Massachusetts
[24] Hu, F., (2008), Der Islam in Shaanxi: geschichte und gegenwart mit einer untersuchung zum islamisch-christlichen dialog in zeiten der globalisierung und des Ökumenismus (Islam in Shaanxi: History and the present with an investigation into IslamicChristian dialogue in times of globalization and ecumenism), $\mathrm{PhD}$, University of Bonn. Germany

[25] Shaanxi Sheng cheng tu, (1893), 陝西省城圖 (Shaanxi sheng cheng tu), Library of congress, https://www.loc. gov/item/gm71005147/, 10/5/2018.

[26] Duze, H., (1999). 杨城之声在海外中 (The liaocheng voice in overseas), Wuzhou Press. Beijing.

[27] Hu, Z. \& Huang, C., (2010), 中国传 统了饰的象征性吾义 (Symbolic semantics of traditional decorations of doors), 社会科学版, Vol. 6, pp: 70-72.

[28] Li, X., (2006). 伊斯”教建筑的门饰艺术 (Decorative arts of Islamic architecture), Tianjing Univ. Press, Tianjing.

[29] Machun, H., (2004). 门的装饰文化 $(\mathrm{Cu}$ ltures of door decorations), 装饭, Vol. 6, pp: 67-68.

[30] Xiyue, L., (2006). 环境艺术设计概伦 (Introduction to environmental art design), Qinghua Univ. Press, China.

[31] Ben, S., (2009). 伊斯”“教建筑之 伊斯 兰教建筑，穆斯林礼拜青真寺 (Islamic architecture, mosques), Press of Architecture House, Beijing.

[32] Guo, Q., (2010). The mingqi pottery buildings of Han dynasty China, 206 BC: AD 220: Architectural representations and represented architecture, Sussex Academic Press, Brighton.

[33] Clement, P., (1983). Courtyard houses, Mimar, Vol. 3, pp: 34-41.

[34] Chenyu, N. \& Tang, X., (2007). 回族古代宗教建筑的文化艺术特征 (Characteristics of Hui minority culture and art of the ancient religious architecture), 西化民族研究 Vol. 4 (55), pp: 15-22.

[35] Gong X., (2006). 伊斯兰建筑史图典 (Dictionary of Islamic architecture history), Chinese Architectural House Press, Beijing. 
[36] Liangsi, C., (2001). 梁思成全集 (Liang Si Cheng collection), Vol. 6, Chinese Architecture Press, Beijing.

[37] Tong, X., (2003). 伊斯背教与北京青 真寺文化 (Mosques and Islamic culture in Beijing), Zhongyang Minzu Univ. Press, Beijing.

[38] Curl, J., (2006). Oxford dictionary of architecture and landscape architecture, $2^{\text {nd }}$ ed., Oxford Univ. Press, NY.

[39] Chen, H. \& Bing, J., Cong Z., (2009). Chinese houses: A pictorial tour of China's traditional dwellings, Reader's Digest Association, NY.

[40] Chung, A., (2004). Drawing boundaries: Architectural images in Qing China, Hawaii Univ. of Hawaii Press, USA.

[41] Deqi, S. (2011). Chinese vernacular $d$ wellings, Cambridge Univ. Press, London

[42] Grazulis, T., (1993). Significant tornadoes 1680-1991/a Chronology and analysis of events, Environmental Films, London

[43] Ligan, L., (2003). 台灣古建築圖解事典 (Graphic codes of ancient architecture in Taiwan), Yanliu Press, Taipei

[44] Xiao, M., (2006). 巍嵬帝都北京历代 建筑 (Long live the emperor: Ancient buildings in Beijing), Qinghua Univ. Press, Beijing

[45] Lu, B. \& Cai, Y., (2006). 中国建筑 艺术 (Chinese architectural art), Zhongxin Press, Beijing

[46] Liu, W., (2006). 宁夏回族建筑艺术 (Arts of Hui architecture in Ningxia), Ningxia People's Press, China.

[47] Knapp, R., (1999). China's living houses: Folk beliefs, symbols, and household ornamentation, University of Hawaii Press, USA.

[48] Gaubatz, P., (1996). Beyond the great wall: Urban form and transformation on the Chinese frontiers, Stanford Univ. Press, USA.

[49] Boden, J., (2008). The wall behind China's open door: Towards efficient intercultural management in China, ASP Edition, Belgium.
[50] Jinxian, H., (2009), 關施䠲築學的1 00個故事 (100 stories on architecture), Hong Mayi Press, China.

[51] Yijing, R., (2006). 美术欣赏(Art appreciation), Qinghua Univ. Press. Beijing:

[52] Liangsi, C., (2006). 清式营造则例 (Structural regulations of Qing dynasty), Qinghua Univ. Press, Beijing.

[53] Zhaojun, H., (1999). 伊斯”教建筑 木结构斗拱的动力实验研究 (Experimental st:udy on dynamic Islamic architecture brackets of wooden structures), 实验力学, Vol. 14 (1), pp: 106-112.

[54] Liyun, H., (2005). 中国古典建筑设计原理分析 (Principle of Chinese classical architecture design), Tianjin Univ. Press, China.

[55] Dong, S., (2009). 北京清真寺建筑装 饰艺术 (Decorative arts of mosque's architecture in Beijing), MA, Collage of Education, University of Zhongyang Minzu, Beijing.

[56] Xiang, Y., (2009). 中国古建筑中的 垂花门 (Chuihuamen entrances of ancient architecture), 山西建筑 Vol. 35 (13), pp: 60-67.

[57] Liang, L., (2005). 千年古寺经典泉州: 记泉州清净寺 (Millennium of temple classic quanzhou inscriptions of Quanzhou Qingjingsi mosque), 胜迹, Vol. 1, pp: 42-44.

[58] Lubian, T., (2011). 略论宋代伊斯兰教建筑 (On Islamic architecture during Song dynasty), 民族历史学研究， Vol. 22 (2), pp: 70-76.

[59] Leixiao, J. \& Wang, H., (2011). 回族历史碑敫的大容分类、地域特征及文 字演变 (A classification content of Hui historical inscriptions, geographical features and character evolution), 回族豜究 Vol. 1, pp: 95-98. 